\title{
Orthodontic Congregate in South Asia Region
}

Dr Rabindra Man Shrestha

Chief Editor, OJN

Orthodontics in Asia-pacific region began to organize formally with the establishment of Asian Pacific Orthodontic Society (APOS) on October 10, 2001 when nine founding country representatives met in Tokyo, Japan. At the charter meeting, Indian Orthodontic Society (IOS) was the only representative from South Asia region. Later, other countries of South Asia represented by Bangladesh Orthodontic Society (BOS), Orthodontic \& Dentofacial Orthopedic Association of Nepal (ODOAN), Pakistan Association of Orthodontics (PAO) and Sri Lanka

Orthodontic Society (SLOS) were inducted as affiliate members of APOS.

Regional orthodontic meeting in South Asia began in 2009 when SAARC Orthodontic Conference was held on August 3-4 in Delhi, India with the theme 'Current perspective in clinical care, education and research'. The conference was held under the aegis of Ministry of External Affairs, Government of India and SAARC Secretariat. The conference was organized by Division of Orthodontics \& Dentofacial Deformities, Center for Dental Education \& Research, All India Institute of Medical Sciences in collaboration with Indian Orthodontic Society. The conference witnessed the presentations on status of orthodontics in SAARC countries by the presenters of Bangladesh, India, Nepal and Sri Lanka during the inaugural session. During the side-line of the conference, the orthodontic representatives of South Asian states formed an ad hoc committee to form South Asian Federation of Orthodontics. The Committee selected Dr OP Kharbanda (India) as Chairman, Dr Zakir Hossian (Bangladesh) as Vice President, Dr Rabindra Man Shrestha (Nepal) as General Secretary, and Dr Ratnakumara Dissanayake (Sri Lanka) as Treasurer with other members. The committee proposed to form the constitution to formalize the Federation and set the regional office at Kathmandu, Nepal.

The Federation; however is still under conception and awaits further discussion among the stakeholders. Eight years after the First SAARC Orthodontic Conference was held; another South Asian orthodontic congregate is taking place in Nepal. Orthodontic \& Dentofacial Orthopedic Association of Nepal is organizing $2^{\text {nd }}$ SouthAsia International Orthodontic Congress and $7^{\text {th }}$ ODOAN Orthodontic Conference on May 16-17, 2017 in Kathmandu Nepal seeking the collaboration of other South Asian orthodontic societies. The theme of the conference is 'Orthodontic excellence through regional cooperation'. The inaugural session of the congress will witness 'South Asia Orthodontic panorama' with the presentations of SAARC nations in precedence to the previous conference alike.

Meanwhile on several occasions, orthodontic societies of South Asia organized international orthodontic conferences within the subcontinent, besides annual national conferences. On many occasions, South Asian orthodontic counterparts have encountered.

Orthodontic \& Dentofacial Orthopedic Association of Nepal in collaboration with Pierre Fauchard Academy-India section jointly organized International Orthodontic and Interdisciplinary Conference at CV Raman Auditorium at Kathmandu University in Dhulikhel, Nepal during November 15-16, 2011 to mark the Silver Jubilee Celebrations of PFA-India. The theme of the conference was 'Orthodontics beyond boundaries'. Bangladesh Orthodontic Society organized 1st International and $2^{\text {nd }}$ National Orthodontic Conference with the theme 'The new horizon in orthodontics' on 27-28 January, 2012 at LGED Conference Hall, Dhaka, Bangladesh.

Indian Orthodontic Society organized $8^{\text {th }}$ Asia Pacific Orthodontic Conference and $47^{\text {th }}$ Indian Orthodontic Conference during November 29 - December 2, 2012 with the theme 'Embracing diversity, enriching orthodontics'. ODOAN organized $3^{\text {rd }}$ International Orthodontic Conference on September 21-22, 2013 in Kathmandu, Nepal with the theme 'Embrace orthodontics with nature'. PAO organized 4th International Conference of Pakistan Association of Orthodontists, held on 
November 20-22, 2015 at Aga Khan University, Karachi, Pakistan. The theme of the conference was 'Quest for excellence in orthodontics'. Sri Lanka Orthodontic Society conducted First International Orthodontic Conference with the theme 'Vistas in orthodontics in paradise' during February 5-7, 2016 in Colombo, Sri Lanka.

Earlier, $12^{\text {th }}$ IOS \& $1^{\text {st }}$ SAARC Orthodontic PG Students' Convention was held at Bharati Vidyapeeth University Dental College, Pune, India in November 2, 2007.

The regional international conferences proffer the opportunities to local orthodontic professionals to exchange and excel in orthodontic service, education, publication, technology, and research. The South Asian professional orthodontic societies may formally or informally unite and strengthen their voice of common interest in international orthodontic arena. It is hoped that, other South Asian states Afghanistan, Bhutan, Maldives and beyond also join the mainstream regional orthodontic activities and acquire the professional benefits to serve its people. And, all orthodontic societies shall continue the legacy of organizing regional orthodontic conferences in a regular basis. 